\title{
Naturally occurring arsenic in geothermal systems in Turkey
}

\author{
A. Baba \\ Izmir Institute of Technology, Geothermal Energy Research and Application Center, Izmir, Turkey
}

\begin{abstract}
Human beings have been benefiting from geothermal energy for different uses since the dawn of the civilization in many parts of the world. One of the earliest uses of geothermal energy was for heating and was used extensively by Romans in Turkey, where is an area of complex geology with active tectonics and high geothermal potential. The highest concentrations of naturally occurring aqueous arsenic (As) are found in certain types of geothermal waters, which are generally related to faults and alteration zone. The especially volcanic activity led to the delineation of wide-ranging areas of alteration within mineral assemblages, from advanced argillic type to silica type to prophylitic type at deep levels. The advanced argillic alteration zones are typified by enrichment of sulfur in volcanic rocks that have been dominant in the geological formation of Turkey and the primary mechanism for the presence of numerous trace elements in earth's crust, including but not limited to arsenic. Also, secondary epithermal gypsum has a high concentration of As in the form of realgar and orpiment along the fracture zones of metamorphic and carbonate aquifers. The temperature of geothermal fluid ranges from 40 to $295^{\circ} \mathrm{C}$ in Turkey. The high arsenic concentrations in geothermal resources have been detected in different part of Turkey from 1 to $6000 \mu \mathrm{g} \mathrm{L}^{-1}$ in geothermal fluids.
\end{abstract}

\section{INTRODUCTION}

Plate tectonics control the thermal conditions in the crust. These large-scale movements of plates produce geothermal systems in different part of the world. For example, geothermal systems in Turkey located in the active Alpine-Himalayan Fold and Thrust Belt where the collision of African and Eurasian plates and also the closure of the Tethys Ocean occurs today (Bozkurt, 2001). The graben systems and major faults accompanied by young volcanism form abundant geothermal areas in tectonically-active in most part of Turkey. Generally, geothermal field in Turkey roughly parallel the trends of the graben-bounding faults, young volcanism and hydrothermally altered areas (Mutlu \& Gülec, 1998; Simsek et al., 2002; Baba \& Ármannsson, 2006; Baba \& Sözbilir, 2012) (Fig. 1).

Turkey is favored by a large number of thermal springs known since classical and even prehistoric times. Most important geothermal exploration studies in Turkey began in 1962 by the General Directorate of Mineral Research and Exploration (MTA). There are a total of about 1,500 thermal and mineral water spring groups sped all over the country (Simsek et al., 2002; MTA, 1980; Simsek, 2009). The highest $\left(295^{\circ} \mathrm{C}\right)$ bottom hole temperatures have been measured in central Turkey. In Turkey, geothermal energy is also used in various applications such as power generation, greenhouse, district heating, industrial processes, and balneology. The installed capacity is $3322 \mathrm{MWt}$ for direct use (heating) and 1053 MWe for power generation (Akkuş, 2017). The application of geothermal energy for power generation has increased exponential in Turkey (Fig. 2).

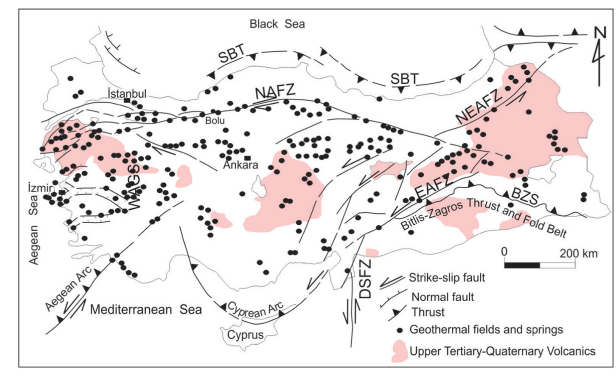

Figure 1. Simplified tectonic map of Turkey showing major neotectonic structures, volcanic province and geothermal spring area in Turkey (from Şimşek et al., 2002; Yiğitbaş et al., 2004).

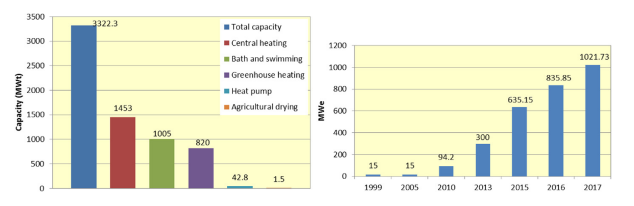

Figure 2. Application of geothermal system in Turkey a) direct use and b) power generation.

\section{ARSENIC IN GEOTHERMAL FLUID}

Based on the tectonic characteristics and the geological structure, many parts of Turkey are likely to have arsenic containing geological formations. Particularly, high arsenic levels have been naturally detected in along the fault system where volcanic, metamorphic and sedimentary formations out croup. The especially 

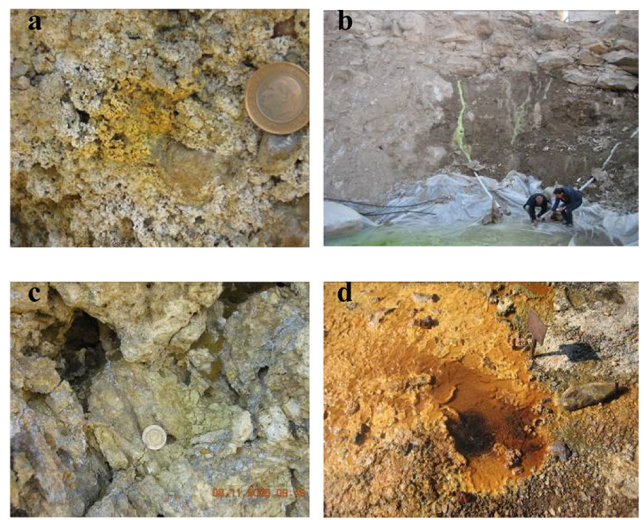

Figure 3. Alteration zone which is including arsenic (a: Lif (Siirt), b: Alaşehir (Manisa), c: Varto (Muş) and d: Tuzla (Çanakkale)).

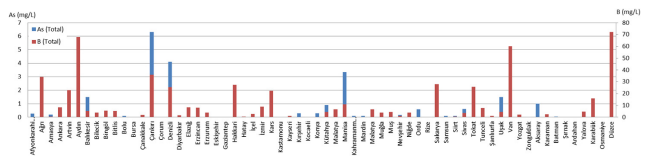

Figure 4. Concentration of arsenic in some geothermal field in Turkey (Some data taken from MTA, 2005).

volcanic activity led to the delineation of wide-ranging areas of alteration within mineral assemblages, from advanced argillic type to silica type to prophylitic type at deep levels (Fig. 3). The advanced argillic alteration zones are typified by enrichment of sulfur in volcanic rocks that have been dominant in the geological formation of Turkey is the primary mechanism for the presence of numerous trace elements in earth's crust, including but not limited to arsenic (Baba \& Gunduz, 2010; Baba \& Sözbilir, 2012). The concentration of arsenic in geothermal fluid changes in each field because of geological properties. The concentration of arsenic is range from 10 to $6936 \mathrm{mg} \mathrm{L}^{-1}$. The highest As concentration was found in the Hamambogazi (Uşak) geothermal spring with values of $6936 \mathrm{mg}$ $\mathrm{L}^{-1}$. The concentration of arsenic in some geothermal field is given in Figure 4. Except for arsenic, boron values also are quite in the geothermal system of Turkey. The concentration of boron reaches about $70 \mathrm{mg} \mathrm{L}^{-1}$ in some geothermal field such as Aydın, Manisa and Düzce Region. Boron concentration is related to volcanic and sedimentary rocks, but may also be controlled by degassing of magma intrusive (Baba \& Armmansson, 2006).

Figure 5 illustrates dominant hydrochemical features of geothermal fluid in Turkey. Each geothermal fluid has different compositions generally most of geothermal fluids which have a deep circulation are of $\mathrm{Na}-\mathrm{HCO}_{3}^{-}$type, whereas shallow fluids are mostly of the $\mathrm{Ca}-\mathrm{HCO}_{3}^{-}$type. Along the coastal region such as western Turkey, hot spring exhibited a Na-Cl type with high concentrations of $\mathrm{Na}^{+}$and $\mathrm{Cl}^{-}$.
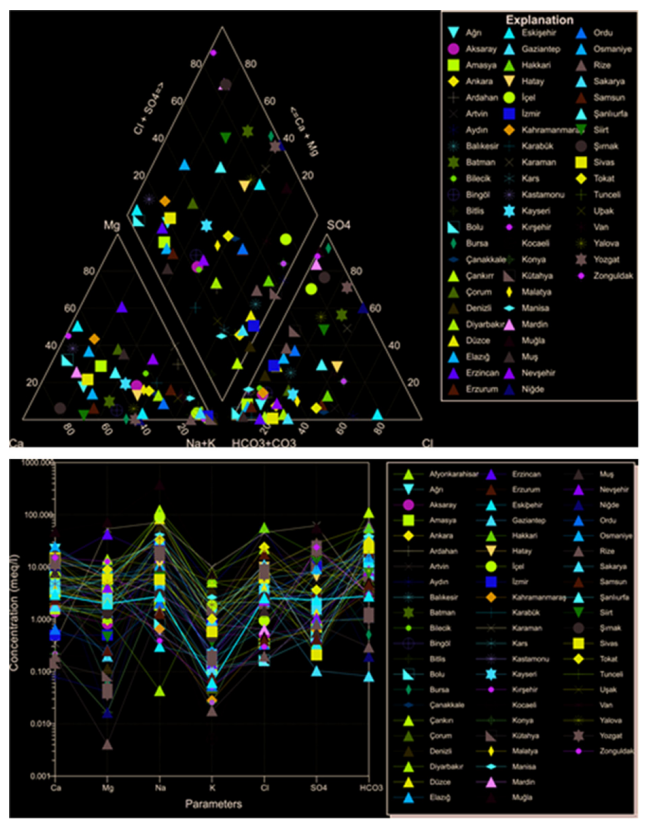

Figure 5. Chemical properties of geothermal fluid in Turkey a) Piper diagram and b) Schoeller diagram.

\section{CONCLUSIONS}

The study shows that geothermal fluid has a different water types in the different region and some geothermal fields have high concentrations of arsenic. Re-injection is one of the important processes to minimize environmental problem and sustainability of the system. It was observed that the deterioration of local shallow groundwater resources through arsenic contamination was due to the mixing of geothermal fluid or utilization of geothermal resources for energy regeneration. Therefore, proper management and control strategy must be adopted in order to ensure environmental safety to freshwater resources which is currently under threat from geothermal (Bundschuh et al., 2013).

\section{REFERENCES}

Akkuş, İ. 2017. Importance of geothermal energy in Turkey. TMMOB, JMO, Mavi. Gezegen. 23: 25-39.

Baba, A. \& Ármannsson, H. 2006. Environmental impact of the utilization of a geothermal area in Turkey. Energ. Source 1(3): 267-278.

Baba, A. \& Gunduz, O. 2010. Effect of alteration zones on water quality: a case study from biga peninsula, turkey. Arch. Environ. Con. Tox. 58(3): 499-513.

Baba, A. \& Sözbilir, H. 2012. Source of arsenic based on geological and hydrogeochemical properties of geothermal systems in Western Turkey. Chem. Geol. 334: 364-377.

Bozkurt, E. 2001. Neotectonics of Turkey - a synthesis. Geodin. Acta 14(1-3): 3-30. 
Bundschuh, J., Maity J. P., Nath B., Baba A., Gunduz O., Kulp T.R., Jean J.S., Kar S., Tseng Y., Bhattacharya P. \& Chen C.Y. 2013. Naturally occurring arsenic in terrestrial geothermal systems of western Anatolia, Turkey: potential role in contamination of freshwater resources. J. Hazard. Mater. 262: 951-959.

Mineral Research and Exploration (MTA). 1980. Hot and Mineral Water Inventory. General Directorate of Mineral Research and Exploration (MTA), MTA Rap., Ankara.

Mineral Research and Exploration (MTA). 2005. Geothermal Resources in Turkey. General Directorate of Mineral Research and Exploration (MTA), MTA Rap.21, Ankara.

Mutlu, H. \& Güleç, N. 1998. Geochemical characteristics of thermal waters from Anatolia (Turkey). J. Volcanol. Geoth. Res. 85: 495-515.
Simsek, S, Yildirim, N., Simsek, Z.N. \& Karakus, H. 2002. Changes in geothermal resources at earthquake regions and their importance. Proceedings of Middle Anatolian Geothermal Energy and Environmental Symposium, pp. $1-13$.

Simsek, S. 2009. Geothermal energy development possibilities in Turkey. NUMOW Conference on 'Geothermal Energy in Turkey', Potsdam-Germany, 1 October, 1-6.

Yigitbas, E., Elmas, A., Sefunc, A. \& Ozer, N. 2004. Major neotectonic features of eastern Marmara region, Turkey: development of the Adapazari-Karasu corridor and its tectonic significance. Geol. J. 39(2): 179-198. 